\title{
Zastosowanie materiału elastycznego do podścieleń protez ruchomych $w$ leczeniu protetycznym pacjentów $w$ wieku senioralnym $z$ rozszczepem podniebienia - opis przypadku
}

\author{
Application of soft material in relining of removable dentures \\ in prosthetic treatment of ederly patients with cleft palate - case report
}

Katedra Protetyki Stomatologicznej, Warszawski Uniwersytet Medyczny

DOI: http://dx.doi.org/10.20883/df.2018.35

\begin{abstract}
STRESZCZENIE
Leczenie pacjentów w wieku senioralnym z nieleczonym wcześniej rozszczepem podniebienia twardego może sprawiać wiele trudności. Artykuł opisuje przypadek pacjenta w wieku 82 lat, z rozszczepem podniebienia po stronie lewej, leczonego z zastosowaniem protezy typu overdenture. Tak zaplanowane leczenie z wykorzystaniem ruchomego uzupełnienia protetycznego podścielonego materiałem elastycznym przynosi wiele korzyści u pacjentów w starszym wieku, u których wcześniej nie zamknięto chirurgicznie szczeliny rozszczepu, pozwalając na zadowalającą rehabilitację narządu żucia i zamknięcie połączenia pomiędzy jamą ustną i nosową.
\end{abstract}

Słowa kluczowe: podścielenie, materiały elastyczne.

\section{ABSTRACT}

Treatment of elderly patients with an untreated cleft of the hard palate may be difficult. This article describes the case of a patient aged 82 with a cleft palate on the left side treated with an over-denture prosthesis relined with elastic material. Removable prosthetic restorations prepared in this way for older people with a cleft and palate enables full rehabilitation of the masticatory system and closing of the mouth-to-nose connection.

Keywords: relining, resilient materials.

\section{Wstęp}

Rozszczep podniebienia twardego jest wrodzoną wadą rozwojową, która może doprowadzić do wielu zaburzeń, m.in. niedosłuchu, zaburzeń układu kostnego i mięśniowego części twarzowej czaszki, a nawet zaburzeń rozwoju emocjonalnego. Wśród noworodków w polskiej populacji występuje średnio 1,7 na 1000 nowo narodzonych. Wadę tę leczy się metodami skojarzonymi chirurgiczno-ortodontycznymi z następową długą rehabilitacją. Metody leczenia zależne są od rozległości wady u danego pacjenta, a terapię zaczyna się już od pierwszych dni życia noworodka, by maksymalnie umożliwić i usprawnić pobieranie pokarmu przez dziecko bez przedostawania się pokarmu do dróg oddechowych. Tego rodzaju leczenie, rozpoczęte $w$ pierwszych dniach życia pacjenta, przynosi dobre rezultaty i może doprowadzić do całkowitej eliminacji wady [1-5].

W przypadku pacjentów dorosłych z nieleczonym wcześniej chirurgicznie rozszczepem pod- niebienia rehabilitacja jest trudna. Łącznie ze zniekształceniami wargi górnej, przetrwałe połączenie pomiędzy jamą ustną a nosową skutkuje ciągłym przedostawaniem się płynów poprzez szczelinę rozszczepu. W takich wypadkach projektowane uzupełnienie protetyczne, oprócz odtworzenia braków zębowych, powinno prowadzić do mechanicznego zamknięcia takiego połączenia. Pacjenci starsi wiekiem z nieleczonym wcześniej rozszczepem podniebienia zgłaszają się do lekarza protetyka najczęściej w celu uzupełnienia braków zębowych częściowych lub całkowitych. Podczas wykonywania nowych uzupełnień należy zwrócić szczególną uwagę na aspekt zamknięcia szczeliny rozszczepu i polepszenie funkcji narządu żucia [5].

\section{Opis przypadku}

Pacjent M.L. po raz pierwszy został przyjęty do leczenia protetycznego w maju 1993 roku, w wieku 
57 lat. Stwierdzono liczne braki zębowe oraz nieleczony wcześniej rozszczep podniebienia i wargi górnej. Pacjent podawał, że $w$ ramach rehabilitacji narządu żucia przeprowadzono leczenie endodontyczne górnych zębów, zaopatrzono je wkładami korzeniowymi z zaczepami kulistymi typu Rhein 83 oraz wykonano protezę nakładową szkieletową z wykorzystaniem uzębienia resztkowego, z retencją na zaczepach kulistych. Łącznik duży protezy szkieletowej pokrywał całą szczelinę rozszczepu. Stabilizacja i retencja tak wykonanego uzupełnienia była opisywana przez pacjenta jako bardzo dobra, natomiast dużym problemem, według opisu pacjenta, było przedostawanie się płynów i resztek pokarmowych do jamy nosowej, szczególnie podczas spożywania posiłków. W żuchwie braki skrzydłowe uzupełniono protezą szkieletową.

W 2001 roku pacjent ponownie zgłosił się z powodu całkowitej utraty retencji i stabilizacji protezy. Należy nadmienić, że pomiędzy 1993 a 2001 rokiem pacjent nie zgłaszał się na wizyty kontrolne i ewentualną wymianę matryc zaczepów precyzyjnych. Zaistniała konieczność usunięcia w szczęce zębów 16 i 26 oraz w żuchwie 35, 34, 44 z powodu zmian periodontologicznych i próchnicy. Stwierdzono konieczność wymiany protez na nowe. Wykonano protezę górną ruchomą akrylową typu over-denture, pokrywającą uzębienie resztkowe zaopatrzone w zaczepy precyzyjne oraz protezę dolną osiadającą. Nowo wykonana proteza górna ulegała jednak często uszkodzeniom, szczególnie w miejscach umocowania na zaczepach precyzyjnych, a także, mimo iż pokrywała całe podniebienie, nie zabezpieczała przed przedostawaniem się płynów do jamy nosa. Protezę podścielono metodą pośrednią materiałem akrylowym twardym. Po oddaniu podścielonej protezy, pacjent wielokrot- nie zgłaszał się na korekty z powodu silnych dolegliwości bólowych oraz nadal przedostających się płynów do jamy nosa. Zdecydowano się na zabieg podścielenia metodą bezpośrednią z zastosowaniem akrylowego materiału elastycznego Softerex (Zhermack, Włochy), występującego obecnie w zmienionej formule jako Villacryl soft. Po tym zabiegu dolegliwości zgłaszane wcześniej przez pacjenta, także przesączanie płynów przez szczelinę rozszczepu, całkowicie ustąpiły. Zalecono kontrolę wykonanych protez co 6 miesięcy. W okresie od 2002 do 2016 roku dwa razy wymieniano protezy na nowe $z$ podścielaniem protezy górnej materiałem elastycznym. Za każdym razem zalecono kontrolę co 6 miesięcy, a wymianę materiału elastycznego w zależności od potrzeby [6-8].

W międzyczasie, w obrębie żuchwy przeprowadzono leczenie z zastosowaniem metody implantoprotetycznej. Wprowadzono pięć implantów i wykonano mosty oparte na implantach uzupełniające braki skrzydłowe. Po kilku latach usunięto implanty w obrębie zębów trzonowych, pozostawiając korony na zębach przedtrzonowych i wykonano ruchome uzupełnienie protetyczne.

W grudniu 2016 roku 82 letni pacjent zgłosił się ponownie w celu wykonania nowych uzupełnień protetycznych. W wywiadzie podawał, że dotychczas użytkowane protezy straciły stabilizację i retencję, a także szczelność przy szczelinie rozszczepu objawiającą się przedostawaniem płynów z jamy ustnej do jamy nosowej oraz problemów z wymową. Pacjent zgłaszał także występowanie dolegliwości bólowych podczas użytkowania protez spowodowanych prawdopodobnie szorstką powierzchnią dośluzową protezy górnej. Zalecono wykonanie zdjęcia pantomograficznego szczęk (Rycina 1). W badaniu przedmiotowym zewnątrz-
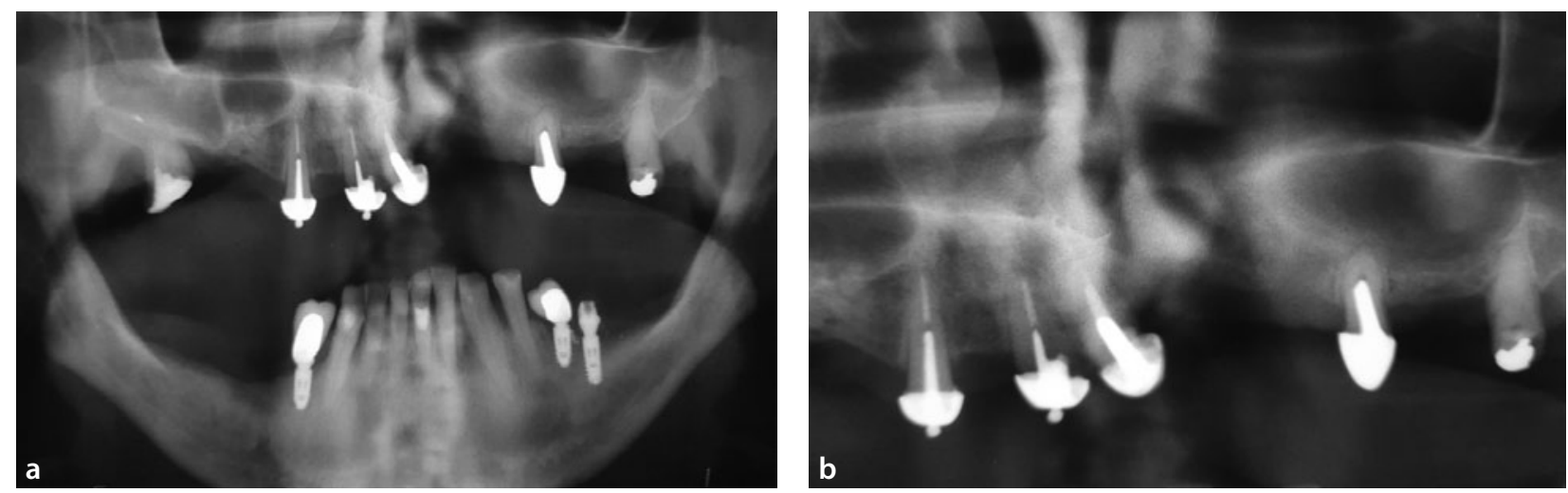

Rycina 1. Zdjęcie pantomograficzne szczęk (a) oraz fragment uwidaczniający rozszczep kości podniebiennej po stronie lewej (b)

Figure 1. Pantomographic picture of jaws (a) and a fragment showing palatal bone cleft on the left side (b) 
ustnym stwierdzono skrócenie odcinka podnosowego twarzy i zapadnięcie wargi górnej oraz obniżenie wysokości zwarcia (Rycina 2). W badaniu wewnątrzustnym stwierdzono występowanie szczeliny rozszczepu w lewej części podniebienia twardego, zęby 13 i 11 zaopatrzone w kuliste zaczepy precyzyjne typu Rhein oraz zęby 21, 23 pokryte metalowymi koronami. Zęby 17 i 27 z wypełnieniami ze znacznie skróconymi koronami klinicznymi. W żuchwie zachowane zęby 33, 32, 31, 41, 42, 43,44 z widocznymi wypełnieniami oraz implanty zaopatrzone w korony w okolicy zębów 34, 35, 45 - jako pozostałość po leczeniu implantoprotetycznym z zastosowaniem mostów i po utracie implantów w okolicy 37 i 47 (Rycina 3). Pacjent użytkował dwie protezy ruchome akrylowe, górną typu overdenture pokrywającą uzębienie resztkowe i dolną częściową osiadającą uzupełniającą braki skrzydłowe. Górna proteza była podścielona materiałem elastycznym pokrywającym całą powierzchnię dośluzową. Według relacji pacjenta materiał podścielający nie był wymieniany od dłuższego czasu.

Oceniając stan użytkowanej protezy, stwierdzono duże zmiany w materiale podścielającym polegające na obniżeniu jego właściwości elastycznych. W całości materiał znacznie uległ stwardnieniu, na jego powierzchni pojawiły się liczne ubytki i przebarwienia. Powierzchnia podścielenia była twarda i chropowata, przyczyniając się do powstawania licznych otarć powodujących odczucia bólowe podczas użytkowania protezy (Rycina 4). Zauważono liczne szpary pomiędzy materiałem podścielającym a płytą protezy, wskazujące na trwałą utratę połączenia obu materiałów. Ponadto materiał podścielający znacznie zmienił swoją bar-
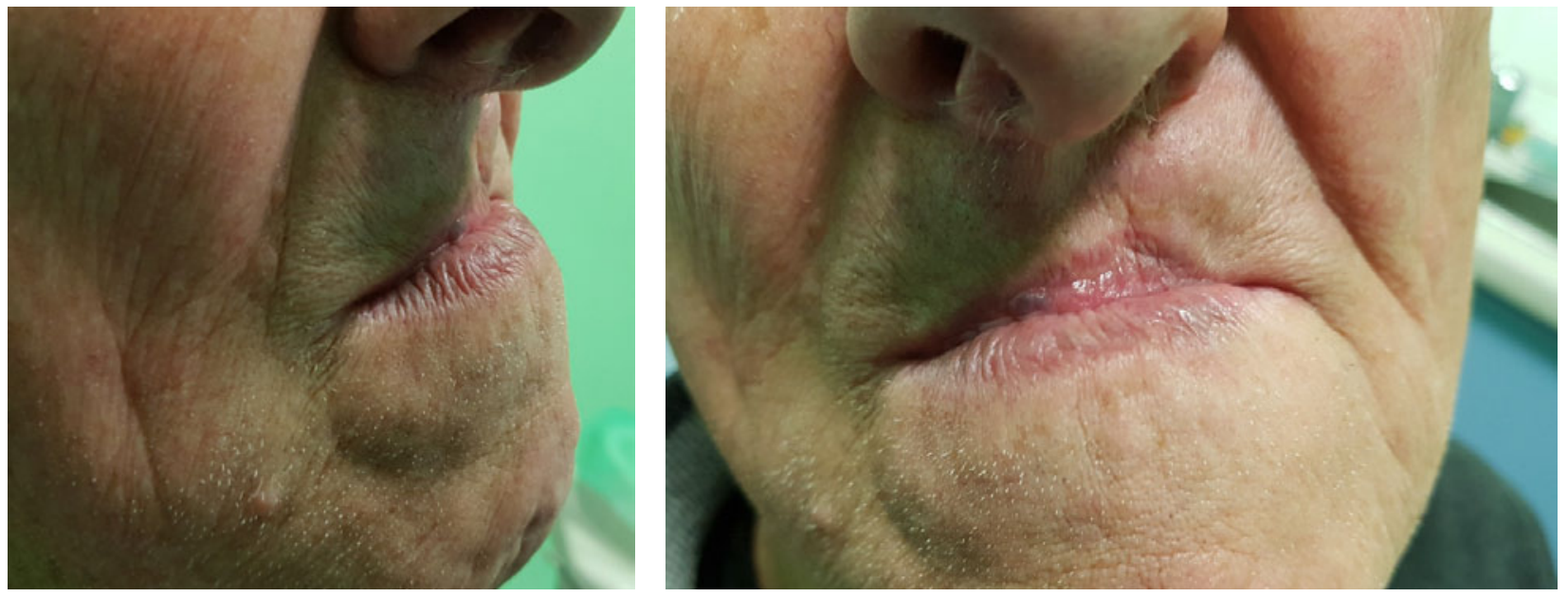

Rycina 2. Dolny odcinek twarzy pacjenta z wyraźnie zapadniętą wargą górną

Figure 2. Lower part of the face with distinctly sunken upper lip

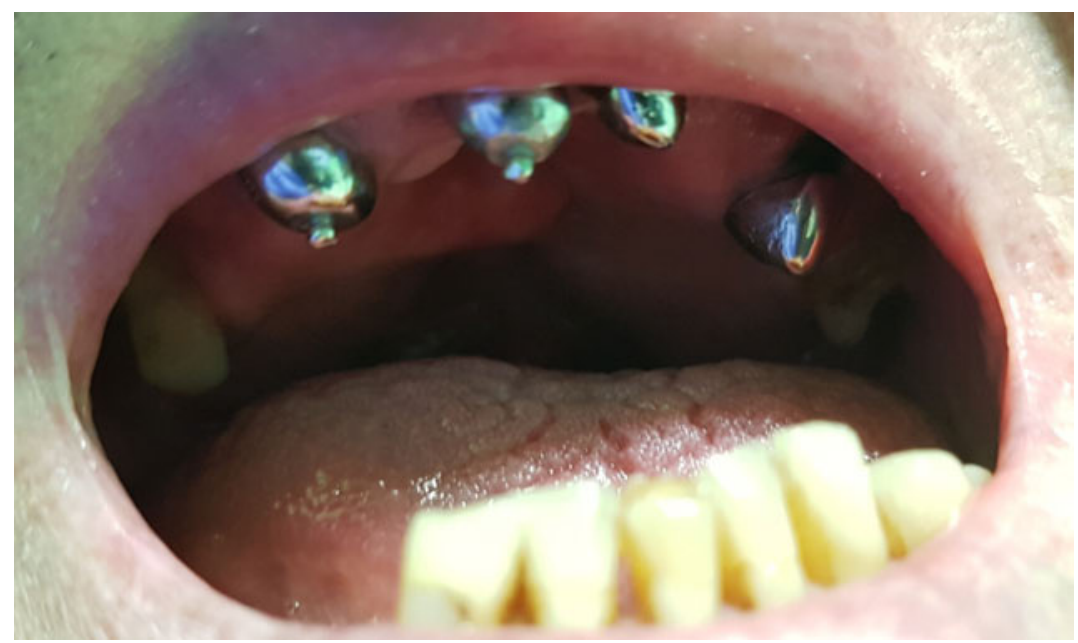

Rycina 3. Zdjęcie wewnątrzustne z uwidocznioną szczeliną rozszczepu i uzębieniem resztkowym

Figure 3. Gap of cleft palate and residual dentition in mascilla 
wę z jasnoróżowej na brązową (Rycina 5). Proteza górna w trakcie wieloletniego użytkowania kilkukrotnie ulegała złamaniu lub pęknięciu akrylowej płyty i następnie naprawiana. Doprowadziło to do osłabienia konstrukcji płyty protezy objawiającego się między innymi jej perforacją w okolicy zębów siecznych (Rycina 6). Pacjent zgłaszał także występowanie nieprzyjemnego zapachu protezy, pomimo stosowanych zabiegów higienicznych. Mając na względzie wszystkie zgłaszane dolegliwości i objawy, a także stan użytkowanego uzupełnienia, stwierdzono konieczność jego wymiany na nowe.

Leczenie protetyczne polegające na wykonaniu nowych uzupełnień protetycznych: górnej protezy ruchomej akrylowej typu overdenture z zamknięciem szczeliny rozszczepu oraz dolnej ruchomej osiadającej, przeprowadzono według standardowych procedur. Uwzględniono zmiany zanikowe podłoża protetycznego oraz uwagi pacjenta dotyczące strefy estetycznej (lepsze podparcie górnej wargi). Po oddaniu protez, na wizycie kontrolnej, pacjent zgłosił problemy z użytkowaniem nowo wykonanych uzupełnień z powodu silnego, wielopunktowego bólu tkanek podłoża protetycznego i przedostawania się treści pokarmowych z jamy ustnej do jamy nosowej poprzez szczelinę rozszczepu. Po wykonaniu korekty, część dolegliwości bólowych ustąpiła, jednakże według opinii pacjenta, proteza górna nadal nie spełniała jego oczekiwań. Ze względu na przyzwyczajenie pacjenta do miękkiej powierzchni protezy, stwierdzono konieczność wykonania podścielenia protezy górnej
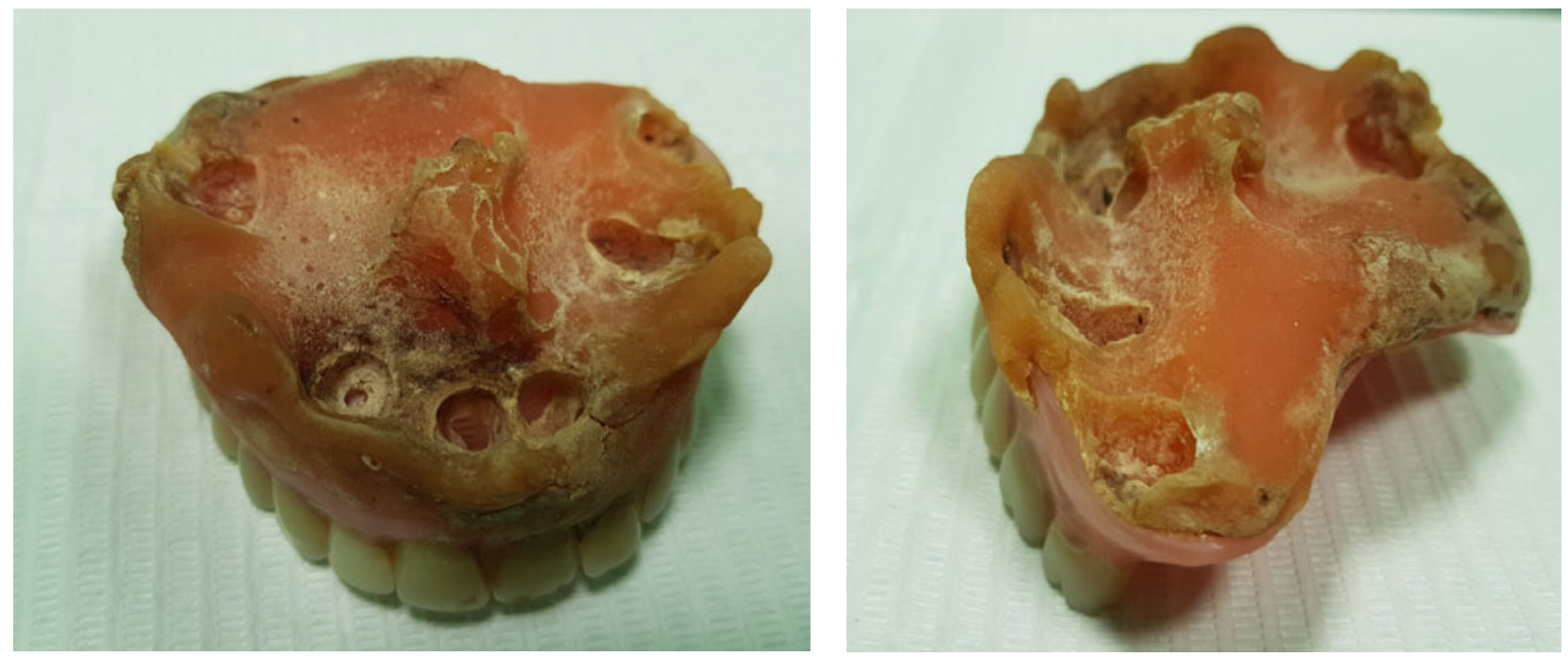

Rycina 4. Dotychczas użytkowana proteza górna podścielona materiałem elastycznym — widoczne liczne przebarwienia i ubytki materiału elastycznego

Figure 4. Existing denture with relined elastic material - many visible discolorations and loss of elastic material
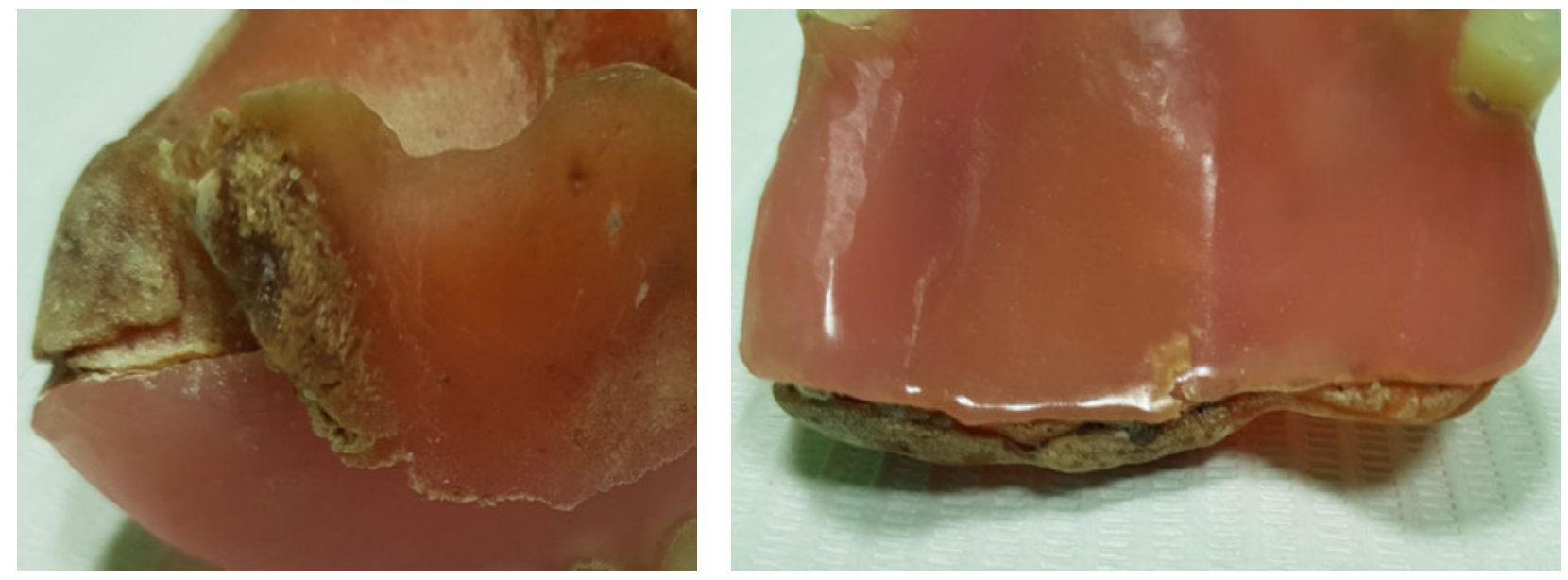

Rycina 5. Dotychczas użytkowana proteza górna podścielona materiałem elastycznym — utracone połączenie materiału podścielającego z płytą protezy w odcinku bocznym i na tylnej granicy

Figure 5. Lack of connection between elastic material and denture plate 


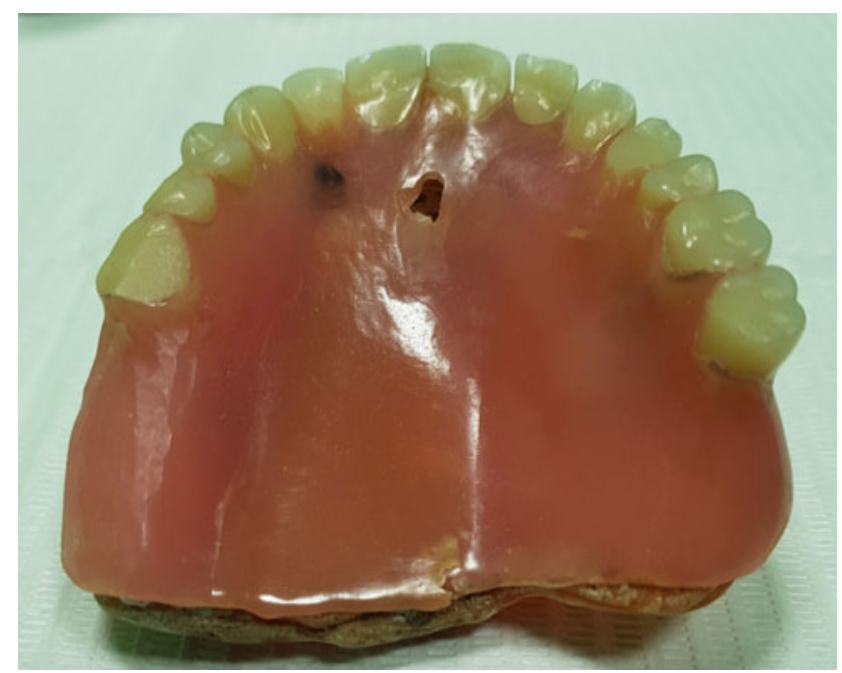

Rycina 6. Ślady po naprawie złamania protezy i otwór spowodowany uszkodzeniem akrylowej płyty

Figure 6. Signs following repair of broken denture and hole saused by damaged acrylic plate
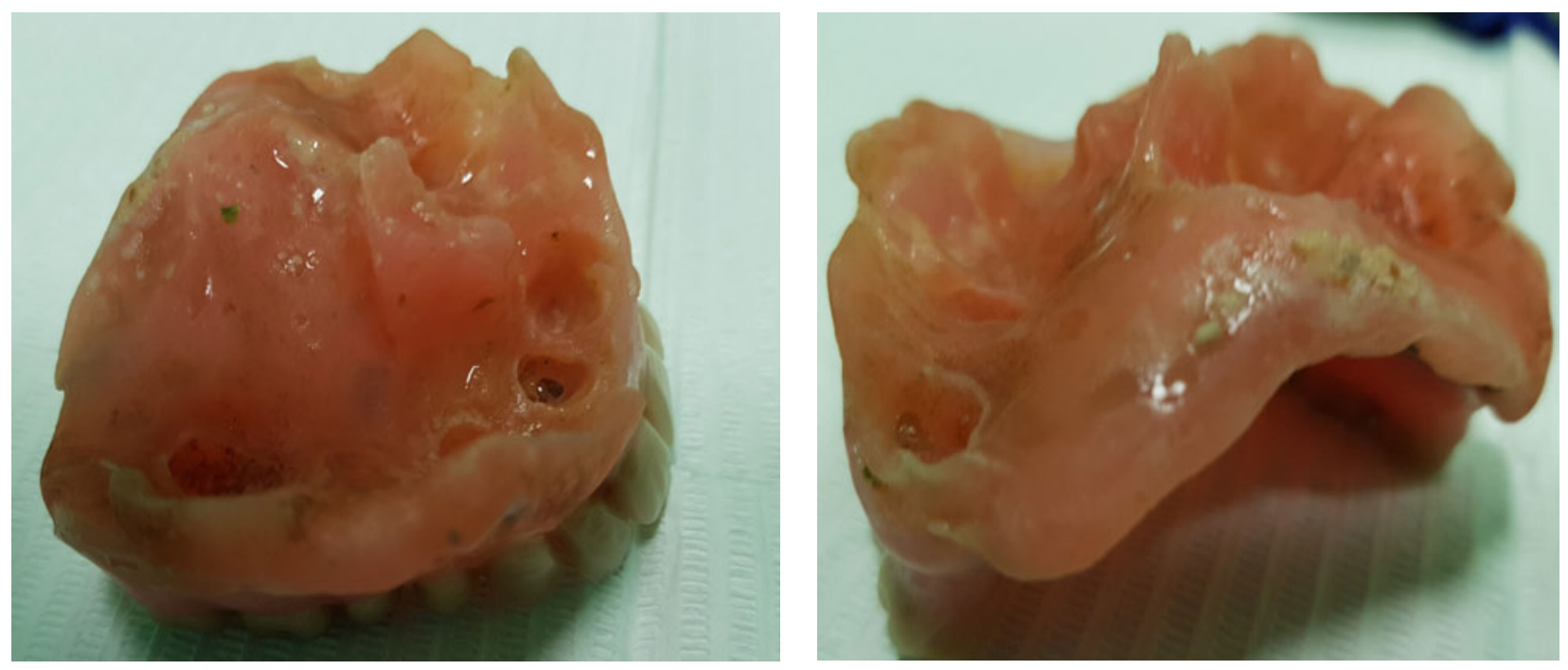

Rycina 7. Nowo wykonana proteza górna podścielona akrylowym materiałem elastycznym po 60 dniach od zabiegu podścielenia - widoczny osad i przebarwienia oraz nieoczyszczone resztki pokarmowe

Figure 7. New upper denture relined with elastic acrylic material after 60 days

materiałem elastycznym Villacryl soft (Zhermapol, Włochy) metodą bezpośrednią.

Poprawa i znaczne zmniejszenie dolegliwości bólowych miały miejsce już bezpośrednio po wykonaniu zabiegu podścielenia. Na wizycie kontroInej pacjent nie zgłaszał problemów w użytkowaniu nowo wykonanej i podścielonej materiałem elastycznym protezy górnej. Dolegliwości bólowe ustąpiły, nie zauważył także przedostawania się płynów do jamy nosowej. Wyznaczono następne wizyty kontrolne po 30 i 60 dniach od wykonania zabiegu podścielenia.

$\mathrm{Na}$ drugiej wizycie kontrolnej pacjent relacjonował nadal brak problemów w użytkowaniu protezy, natomiast podczas oględzin powierzchni uzupełnienia protetycznego, w kilku miejscach stwierdzono początki przebarwień elastycznego materiału i zaleganie resztek pokarmowych (Rycina 7). Dokonano oczyszczenia powierzchni materiału i ponownie pokryto powierzchnię lakierem uszczelniającym (zgodnie z instrukcją producenta), a także poinstruowano pacjenta o sposobie zabiegów higienicznych protezy podścielonej materiałem elastycznym.

\section{Podsumowanie}

Protetyczne leczenie pacjentów w wieku senioralnym z nieleczonym wcześniej rozszczepem 
podniebienia twardego niejednokrotnie, zależnie od rozległości wady, jest trudne i może być długotrwałe. Mimo iż starsi pacjenci w większości są użytkownikami protez od dłuższego czasu, adaptacja do nowych uzupełnień, szczególnie $w$ tak trudnych warunkach, najczęściej jest długotrwała i wymaga wielu korekt, co jest zgodne z obserwacjami wielu autorów [9-13]. Niekontrolowane przedostawanie się płynów z resztkami pokarmowymi z jamy ustnej do nosowej, przy postępującym $z$ wiekiem spadkiem napięcia mięśni, może prowadzić do aspirowania wyżej wymienionych substancji do górnych dróg oddechowych, co może być przyczyną stanów zapalnych. W sporadycznych przypadkach może dojść nawet do zachłystowego zapalenia płuc. Obok uzyskania prawidłowych warunków zwarciowych, stabilizacji i retencji ruchomych uzupełnień protetycznych, niezmiernie ważne jest uzyskanie szczelności protezy, szczególnie w okolicy niezamkniętej szczeliny rozszczepu, by nie dopuszczać do przedostawania się płynów i treści pokarmowych z jamy ustnej do jamy nosowej poprzez tę szczelinę [7, 8, 12, 13]. Dobrym rozwiązaniem jest opisane na przykładzie leczonego pacjenta wykonanie protezy z elastycznym podścieleniem, uszczelniającym ubytek $w$ miejscu rozszczepu. Należy jednak dokładnie poinformować pacjenta o właściwościach danego materiału, o jego nasiąkliwości, która prowadzi do deponowania różnych substancji w strukturze materiału podścielającego, a także o specyfice zabiegów higienicznych, by nie doprowadzić do zbyt szybkiej degradacji powierzchni zastosowanego materiału elastycznego $[10,11,14,15]$.

\section{Oświadczenia}

Oświadczenie dotyczące konfliktu interesów

Autorzy deklarują brak konfliktu interesów

w autorstwie oraz publikacji pracy.

\section{Źródła finansowania}

Autorzy deklarują brak źródeł finansowania.

\section{Piśmiennictwo}

[1] Antoszewski B. Wielkość środowiska pochodzenia a częstość występowania rozszczepów wargi i podniebienia u noworodków z terenu województwa Łódzkiego. Nowiny Lekarskie. 2007;76:5, 414-417.

[2] Kaczmarek E, Małkiewicz E. Przydatność modelowania log?liniowego do wieloczynnikowej analizy epidemiologicznej — przykład badania populacyjnego występowania rozszczepów podniebienia pierwotnego i/lub wtórnego w latach. 1998-1999 w Polsce, Dent. Med. Probl.. 2005;42:3, 419-424.

[3] Morén S, Lindestad PÅ, Holmström M, Mani M. Voice Quality in Adults Treated for Unilateral Cleft Lip and
Palate: Long-Term Follow-Up After One- or Two-Stage Palate Repair. Cleft Palate Craniofac J. 2018;1: 127-133.

[4] Szeląg J, Penkala J. Leczenie ortodontyczne rozszczepów podniebienia pierwotnego i wtórnego w uzębieniu mieszanym i wczesnym stałym. Dent Med Probl. 2007;44(1):45-49.

[5] Forsetlund L, Semb G, arah MG, Flottorp S. The Scientific Knowledge Base for Treatment of Patients with Cleft Lip, Alveolus and Palate. Report from Norwegian Knowledge Centre for the Health Services. 2009;10.

[6] Kucharski Z. Własności fizyczne materiałów elastycznych stosowanych w protetyce stomatologicznej. Protet Stomatol. 2008;58:134-7.

[7] Brożek R, Koczorowski R. Zastosowanie elastycznych materiałów do wyścieleń protez ruchomych w leczeniu bezzębnych pacjentów w wieku podeszłym. Nowiny Lekarskie. 2009;78:256-261.

[8] Kucharski Z. Podścielenia protez ruchomych z wykorzystaniem materiałów elastycznych - przyczyny niepowodzeń. Protet Stomatol. 2012;62(1):38-43.

[9] Mutluay MM, Tezvergil-Mutluay A. The influence of cyclic stress on surface properties of soft liners. Odontology. 2017;105:214-221.

[10] Kucharski Z, Gasiuk P. Podścielenie protez materiałem elastycznym jako alternatywna metoda leczenia pacjentów ze zdiagnozowaną sklerodermią opis przypadku. Protet Stomatol. 2013;4:307-312.

[11] Krunić N, Kostić M, Petrović M, Igić M. Oral health-related quality of life of edentulous patients after complete dentures relining. Vojnosanit Pregl. 2015;72(4): 307-11.

[12] Kucharski Z, Dominiak K. Zastosowanie materiałów elastycznych w leczeniu protetycznym bezzębia u pacjenta po zabiegu osteosyntezy trzonu żuchwy. Protet Stomatol. 2013;63(2):134-139.

[13] Pisani MX, Malheiros-Segundo Ade L, Balbino KL, de Souza RF, Paranhos Hde F, da Silva C. H. Oral health related quality of life of edentulous patients after denturerelining with a silicone-based soft liner. Gerodontology. 2012;29(2):74-80.

[14] Mutluay MM, Ruyter I. E. Evaluation of bond strength of soft relining materials to denture base polymers. Dent Mater. 2007;23(11):1373-81.

[15] Mohammed HS, Singh S, Hari PA, Amarnath GS, Kundapur V, Pasha N, Anand M. Evaluate the Effect of Commercially Available Denture Cleansers on Surface Hardness and Roughness of Denture Liners at Various Time Intervals. Int J Biomed Sci. 2016;12(4):130142.

Zaakceptowano do edycji: 2018-10-16 Zaakceptowano do publikacji: 2018-12-05

Adres do korespondencji:

ul. Nowogrodzka 59, 02-006 Warszawa 